\title{
Rates of pulmonary infection by pentastomids in lizards species from a restinga habitat in northeastern Brazil
}

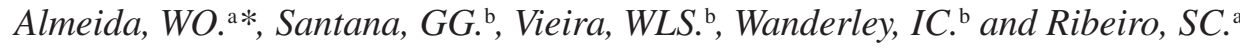 \\ ${ }^{a}$ Departamento de Química Biológica, Universidade Regional do Cariri - URCA, \\ Rua Cel. Antônio Luiz, 1161, CEP 63105-000, Crato, CE, Brazil \\ bPrograma de Pós-Graduação em Ciências Biológicas (Zoologia), \\ Laboratório/Coleção de Herpetologia, Departamento de Sistemática e Ecologia, CCEN, \\ Universidade Federal da Paraíba - UFPB, João Pessoa, PB, Brazil \\ *e-mail: walmeida@urca.br
}

Received October 4, 2007 - Accepted January 28, 2008 - Distributed February 28, 2009

\begin{abstract}
Pulmonary parasitism by pentastomids was examined in two lizard species inhabiting an area of restinga vegetation (coastal sand dunes) situated in the municipality of Mataraca ( $6^{\circ} 29^{\prime} \mathrm{S}$ and $\left.34^{\circ} 56^{\prime} \mathrm{W}\right)$, on the extreme northern coast of Paraíba State, Brazil. A total of 123 lizards were collected, being 75 specimens of Micrablepharus maximiliani (Gymnophtalmidae) and 48 specimens of Cnemidophorus ocellifer (Teiidae). Only a single species of Pentastomida (Raillietiella mottae) was found parasitizing three females $M$. maximiliani, with a prevalence of $4 \%$ and an average infection intensity of $2.3 \pm 1.3$ (range 1-5). The infection rate by pentastomids encountered in the present study was similar to that seen with other species of restinga lizards. Raillietiella mottae is a generalist parasite species that is probably transmitted by common and widely distributed insects making up part of the diet of many insectivorous lizard species from northeastern Brazil.
\end{abstract}

Keywords: parasitism, lizards, Neotropical region.

\section{Infecção pulmonar por pentastomídeos em lagartos de restinga do nordeste brasileiro}

\begin{abstract}
Resumo
O parasitismo por pentastomídeos foi estudado em duas espécies de lagartos de restinga no Nordeste brasileiro Foram realizadas coletas no município de Mataraca (6²9' S e $\left.34^{\circ} 56^{\prime} \mathrm{W}\right)$, extremo norte do litoral do Estado da Paraíba. Foram coletados 123 lagartos, 75 Micrablepharus maximiliani (Gymnophtalmidae) e 48 Cnemidophorus ocellifer (Teiidae). Apenas uma única espécie de Pentastomida, Raillietiella mottae, foi encontrada parasitando três fêmeas de M. maximiliani, com prevalência de $4 \%$ e intensidade média de infecção de 2,3 $\pm 1,3$ (amplitude 1-5). Os dados de prevalência encontrados são relativamente semelhantes aos de outras espécies de lagartos de restinga parasitados por pentastomídeos. Raillietiella mottae é uma espécie de parasita generalista e deve ser transmitida por insetos comuns e de ampla distribuição geográfica presentes na dieta de várias espécies de lagartos insetívoros no Nordeste brasileiro.
\end{abstract}

Palavras-chave: parasitismo, lagartos, região Neotropical.

\section{Introduction}

Pentastomids are pulmonary parasites of vertebrates, principally reptiles, but they have been relatively poorly studied in the neotropical region (Almeida and Christoffersen, 2002). A better comprehension of the biology of these parasites will be important to understand the mechanisms of infection by these parasites, for the conservation of their reptilian hosts, and for developing reptile management strategies in zoos and similar breeding facilities (Klingenberg, 1993; Marcogliese, 2004).

In spite of important work done in Brazil in the areas of reptilian systematics, taxonomy, and phylogeny (Motta, 1963a, b; Motta and Gomes, 1968; Rego, 1983,
1984; Almeida and Christoffersen, 1999; Almeida et al., 2006a, b; 2008a, b), only eight lizard species have so far been examined to determine their levels of pentastomid infection (prevalence and average infection intensity, sensu Bush et al., 1997): (1) Mabuya agilis infected by the larva of Raillietiella sp. (in coastal sand dune areas in the states of Rio de Janeiro and Sergipe) (Vrcibradic et al., 2002); (2) Cnemidophorus abaetensis and (3) $C$. ocellifer infected by $R$. aff. furcocerca (in coastal sand dune areas of Bahia State) (Dias et al., 2005); (4) Tropidurus hispidus infected by $R$. mottae (in an area of caatinga dryland vegetation in the states of Ceará and 
Paraíba) (Almeida et al., 2008b, c); (5) Hemidactylus mabouia infected by $R$. frenatus and $R$. mottae, in urban areas in the cities of Barbalha, Ceará State (Anjos et al., 2007, 2008) and João Pessoa, Paraíba State (Almeida et al., 2008d); (6) T. semitaeniatus, (7) Phyllopezus periosus, and (8) P. pollicaris infected by $R$. mottae (in an area of caatinga in Paraíba State) (Almeida et al., 2008c).

The objectives of the present study were: i) to examine the composition of the pentastomid fauna in the lizards Micrablepharus maximiliani and Cnemidophorus ocellifer from an area of resting a vegetation in northeastern Brazil, and ii) determine their levels of infection.

\section{Materials and Methods}

Lizards were collected in an area of restinga vegetation (coastal sand dunes) situated in an particular area property of the Lyondell Chemical Company, in the municipality of Mataraca (6 $6^{\circ} 29^{\prime} \mathrm{S}$ and $34^{\circ} 56^{\prime} \mathrm{W}$ ), on the extreme northern coast of Paraíba State, Brazil. The regional climate is hot and humid, and the predominant restinga vegetation varies from open physiognomies on coastal sand dunes to forests on inland sandy plains (Oliveira-Filho and Carvalho, 1993).

Surveys were undertaken during both the dry season (November and December, 2005) and the rainy season (May, 2006) using standard herpetological collection methods (see Auricchio and Salomão, 2002), including 150 pit-fall traps and complementary collections by hand.

Collected lizards were quickly euthanized by freezing, and then fixed and preserved in 70\% ethanol. Lizard snout-vent length (SVL) was measured with a ruler (to the nearest $0.1 \mathrm{~mm}$ ). Voucher specimens were deposited in the Herpetology Collection of the Department of Systematics and Ecology of the Federal University of Paraíba, in João Pessoa, Paraíba State, Brazil.

The lungs were removed from the lizards and then examined for the presence of pentastomids using an optical stereomicroscope. Pentastomids found were either preserved in $70 \%$ alcohol or mounted on slides and treated with Hoyer's mounting medium. Pentastomid identification was based on the hook and copulatory spiculae dimensions of the males (measured with the aid of an optical microscope fitted with a micrometer eyepiece) (Ali et al., 1984; 1985; Almeida et al., 2008b).

Throughout this text, ecological terms related to parasitology follow Bush et al. (1997).

\section{Results}

Of the total of 75 specimens of $M$. maximiliani collected, 35 were adult females (mean SVL $41.5 \pm 0.4 \mathrm{~mm}$; range $36.5-45.5 \mathrm{~mm}$ ), and 40 were adult males (mean SVL $38.5 \pm 0.2 \mathrm{~mm}$; range 34.7-41.2 $\mathrm{mm}$ ).

Only a single species of Pentastomida (Raillietiella mottae, see Figures 1-4 Almeida et al., 2008b) was found parasitizing three individual $M$. maximiliani fe- males (mean SVL $40.5 \pm 1.7 \mathrm{~mm}$; range $37-42.6 \mathrm{~mm}$ ). The prevalence of infection in M. maximiliani was $4 \%$ $(3 / 75)$ and the average infection intensity was $2.3 \pm 1.3$ (range 1-5). This is the first record of pulmonary infections in Gymnophtalmid lizards in Brazil.

Of the total of 48 specimens of $C$. ocellifer collected, 07 were females (mean SVL $61.3 \pm 1.5 \mathrm{~mm}$; range 56-69 $\mathrm{mm}$ ), and 41 were males (mean SVL $58.9 \pm 1.1 \mathrm{~mm}$; range $49-82.4 \mathrm{~mm}$ ) and all C. ocellifer examined were healthy and no lung infections by pentastomids were observed.

\section{Discussion}

The pulmonary pentastomid infection rate encountered in the present study for $M$. maximiliani was relatively very similar to that observed in three other lizard species from Brazilian restinga habitats: Mabuya agilis $=$ 3.6-9.0\% (Vrcibradic et al., 2002), C. ocellifer $=2.5 \%$ (Dias et al., 2005) and C. abaetensis 6.0\%; (Dias et al., 2005). However, the infection rates reported here were lower than the infection levels observed, and much lower than the infection levels by $R$. mottae reported from caatinga dryland areas in northeastern Brazil: Tropidurus hispidus $=11.1 \%$ (Almeida et al., 2008b, c); Phyllopezus periosus $=66.7 \%$ (Almeida et al., 2008c); . pollicaris $=$ 16.6\% (Almeida et al., 2008c); Tropidurus semitaeniatus $=13.3 \%$ (Almeida et al., 2008c); and Hemidactylus mabouia $=43.2 \%$ (Anjos et al., 2007; 2008) and 20\% (Almeida et al., 2008d).

In terms of the average intensities of pentastomid infections, no patterns have emerged with regard to the environments examined so far in Brazil. The lowest average infection intensity levels were observed in: $M$. agilis $=1.0 \pm 0.0$ (Vrcibradic et al., 2002); C. ocellifer $=1.0 \pm 0.0$ (Dias et al., 2005); . hispidus $=$ $1.0 \pm 0.0$ (Almeida et al., 2008c); H. mabouia $=$ $1.8 \pm 1.4$ (Anjos et al., 2007) and $1.3 \pm 0.2$ (Almeida et al., 2008d); while the largest levels were reported for C. abaetensis $=4.5 \pm 0.0$ (Dias et al., 2005); . hispidus $=$ $6.0 \pm 1.4$ (Almeida et al., 2008b); P. periosus $=5.3 \pm$ 2.0 (Almeida et al., 2008c); $P$. polycaris $=5.0$ (Almeida et al., 2008c); and T. semitaeniatus $=4.0 \pm 3.0$ (Almeida et al., 2008c).

The apparent absence of pentastomids in C. ocellifer in the present survey may be due to the parasite still not attaining and infected lizards from this population or, alternatively due to the relatively low sampling size. This lizard has been reported as hosting $R$. aff. furcocerca - although at a low frequency and with relatively low average infection intensities (Dias et al., 2005). Studies of Brazilian snakes have indicated that the pentastomid Cephalobaena tetrapoda utilizes small vertebrates as intermediate hosts (Almeida et al., 2006a; 2007; 2008a). Considering that $C$. ocellifer has been found to be the host of pentastomids (Dias et al., 2005) it is possible that C. ocellifer (which constitutes part of the diet of these 
snakes; Vitt and Vangilder, 1983) may be one of these intermediate hosts.

In the caatinga region in the interior of northeastern Brazil, $R$. mottae has been identified as a generalist parasite in the lungs of H. mabouia, T. hispidus, $T$. semitaeniatus, $P$. periosus, and $P$. pollicaris. All of these lizards are known to ingest termites and ants as part of their diet, and Almeida et al. (2008b, c) has suggested that these insects may constitute intermediate hosts for this parasite. Termites have also been identified as a principal food items in the diet of $C$. ocellifer in the Brazilian cerrado (savanna) region (Mesquita and Colli, 2003). An analysis of the stomach contents of the specimens of $C$. ocellifer and M. maximiliani encountered in the present study identified the termite Nasutitermes corniger as a major food item. This termite species has a wide geographic distribution in the neotropical region, and it is encountered in the Amazonian and Atlantic Coastal forests as well as in the cerrado and caatinga biomes (Vasconcellos et al., 2005). Although at this time we do not know if termites are intermediate hosts for pentastomid for M. maximiliani, additional studies are necessary to determine if these insects are in fact intermediate hosts for $R$. mottae, and if the distribution of this parasite is as ample as that of the termites.

It is quite possible that gymnophtalmids, teiidaes, and tropidurids occupy overlapping micro-habitats (Vitt, 1991; Bergallo and Rocha, 1994). As such, the occurrence of $R$. mottae in tropidurids (Almeida et al., 2008b, c) and gymnophtalmids (present study) may be related not only to overlapping dietary components but also to the exploitation of the same micro-habitats in a given locality.

Acknowledgements - The authors would like to thank FUNCAP - Fundação Cearense de Apoio ao Desenvolvimento Científico e Tecnológico (Process number 9913/06 - Contract 0006-00/ 2006) for the research grant awarded to WO. Almeida; the Fundação Coordenação de Aperfeiçoamento de Pessoal de Nível Superior (CAPES) for the scholarship awarded to GG. Santana; the Brazilian Institute for the Environment and Natural Resources (IBAMA) for the permit to collect lizards from protected areas (CGFAP/ IBAMA 02007.001009/2004); A. Vasconcellos (UFRN) for the identification of the termites as well as additional information concerning their biogeography); and RR. Funch (UEFS) for the review and translation of the manuscript to English.

\section{References}

ALI, JH., RILEY, J. and SELF, JT., 1984. A revision of the taxonomy of pentastomid parasites (genus Raillietiella Sambon, 1910) from American snakes and amphisbaenians. Systematic Parasitology, vol. 6, no. 2, p. 87-97.

-, 1985. A review of the taxonomy and systematics of the pentastomids genus Raillietiella Sambon, 1910 with a description of a new species. Systematic Parasitology, vol. 7, no. 2, p. 111-123.
ALMEIDA, WO. and CHRISTOFFERSEN, ML., 1999. A cladistic approach to relationships in Pentastomida. The Journal of Parasitology, vol. 85, no. 4, p. 695-704.

-, 2002. Pentastomida. In MORRONE, J. and LLORENTEBOUSQUETS, J. (Eds.). Biodiversidad, Taxonomía y Biogeografía de Artrópodos de México: hacia una síntesis de su conocimiento. México: Universidad Nacional Autónoma de México. 690 p.

ALMEIDA, WO., BRITO, SV., FERREIRA, FS. and CHRISTOFFERSEN, ML., 2006a. First record of Cephalobaena tetrapoda (Pentastomida: Cephalobaenidae) as a parasite on Liophis lineatus (Ophidia: Colubridae) in Northeast Brazil. Revista Brasileira de Biologia = Brazilian Journal of Biology, vol. 66 , no. 2 a, p. 559-564.

ALMEIDA, WO., FERREIRA, FS., BRITO, SV. and CHRISTOFFERSEN, ML., 2006b. Raillietiella gigliolii (Pentastomida) infecting Amphisbaena alba (Squamata, Amphisbaenidae): a first record for Northeast Brazil. Revista Brasileira de Biologia = Brazilian Journal of Biology, vol. 66, no. 4, p. 29-41.

ALMEIDA, WO., VASCONCELLOS, A., FREIRE, EMX. and LOPES, SG., 2007. Prevalence and intensity of pentastomid infection in two species of snakes from Northeast Brazil. Revista Brasileira de Biologia $=$ Brazilian Journal of Biology, vol. 67 , no. 4 , p. $759-763$.

ALMEIDA, WO., COSTA, TBG., FREIRE, EMX. and VASCONCELLOS, A., 2008a. Pentastomid infection in Philodryas nattereri Steindachner, 1870 and Oxybelis aeneus (Wagler, 1824) (Squamata: Colubridae) in a caatinga of Northeastern Brazil. Revista Brasileira de Biologia = Brazilian Journal of Biology, vol. 68, no. 1, p. 193-197.

ALMEIDA, WO., FREIRE, EMX. and LOPES, SG., 2008b. A new species of Pentastomida infecting Tropidurus hispidus (Squamata: Tropiduridae) from caatinga in Northeastern Brazil. Revista Brasileira de Biologia = Brazilian Journal of Biology, vol. 68, no. 1, p. 199-203.

ALMEIDA, WO., SANTANA, GG., VIERIA, WLS., WANDERLEY, I., FREIRE, EMX. and VASCONCELLOS, A., 2008c. Pentastomid, Raillietiella mottae, infecting lizards in an area of Caatinga, Northeast, Brazil. Revista Brasileira de Biologia $=$ Brazilian Journal of Biology, vol. 68, no. 2, p. $427-431$

ALMEIDA, WO., SANTANA, GG., VIERIA, WLS. and WANDERLEY, I., 2008d. Infection rates of pentastomids on lizards in urban habitats from Brazilian Northeast. Revista Brasileira de Biologia = Brazilian Journal of Biology, vol. 68, no. 4 , p. 885-888.

ANJOS, LA., ALMEIDA, WO., VASCONCELLOS, A., FREIRE, EMX. and ROCHA, CFD., 2007. The alien and native pentastomids fauna of an exotic lizard population from Brazilian Northeast. Parasitology Research, vol. 101, no. 3, p. 627-628.

-, 2008. Pentastomids infecting an invader lizard, Hemidactylus mabouia (Gekkonidae) in Northeastern Brazil. Revista Brasileira de Biologia = Brazilian Journal of Biology, vol. 68, no. 3, p. 611-615.

AURICCHIO, P. and SALOMÃO, MG. (Orgs.). 2002. Técnicas de coleta e preparação de vertebrados para fins científicos $e$ didáticos. São Paulo: Instituto Pau Brasil de História Natural. $348 \mathrm{p}$. 
BERGALLO, HG. and ROCHA, CFD., 1994. Spatial and trophic niche differentiation in two sympatric lizards (Tropidurus torquatus and Cnemidophorus ocellifer) with different foraging tactics. Australian Journal of Ecology, vol. 19, no. 1, p. 72-75.

BUSH, AO., LAFFERTY, KD., LOTZ, JM. and SHOSTAK, AW., 1997. Parasitology meets ecology in its own terms: Margulis et al. revisited. The Journal of parasitology, vol. 83, no. 4 , p. 575-583.

DIAS, EJR., VRCIBRADIC, D. and ROCHA CFD., 2005. Endoparasites infecting two species of whiptail lizards (Cnemidophorus abaetensis and $C$ ocellifer; Teiidae) in a restinga habitat of northeastern Brazil. Herpetological Journal, vol. 15 , no. 2 , p. $133-137$.

KLINGENBERG, RJ., 1993. Understanding reptile parasites. Irvine: Advanced Vivarium Systems. 83p.

MESQUITA, DO. and COLLI, GR., 2003. The ecology of Cnemidophorus ocellifer (Squamata, Teiidae) in a Neotropical Savanna. Journal of Herpetology, vol. 37, no. 3, p. 498-509.

MARCOGLIESE, DJ., 2004. Parasites: small players with crucial roles in the ecological theater. Ecohealth, vol. 1, no. 2, p. 151-164.

MOTTA, CS., 1963a. Considerações sobre o gênero Cephalobaena Heymons, 1922 (Linguatulida), Cephalobaena tetrapoda. Atas da Sociedade de Biologia do Rio de Janeiro, vol. 7, no. 4, p. 7-8.

-, 1963b. Considerações sobre o gênero Raillitiella Sambon, 1910. Atas da Sociedade de Biologia do Rio de Janeiro, vol. 7 , no. 2, p. 8-10.
MOTTA, CS. and GOMES, DC., 1968. Sobre um novo gênero e uma nova espécie de Cephalobaenidae (Linguatulida, Cephalobaeniformia). Atas da Sociedade de Biologia do Rio de Janeiro, vol. 12, no. 1, p. 7-9.

OLIVEIRA-FILHO, AT. and CARVALHO, DA., 1993. Florística e fisionomia da vegetação no extremo norte do litoral da Paraíba. Revista Brasileira de Botânica, vol. 16, no. 1, p. $115-130$

REGO, AA., 1983. Pentastomídeos de répteis do Brasil: revisão dos Cephalobaenidae. Memórias do Instituto Oswaldo Cruz, vol. 78 , no. 4, p. 399-411.

-, 1984. Sinopse dos pentastomídeos da região nentropical. Garcia da Orta, Serie Zoologia, vol. 11, no. 1-2, p. 45-56.

VASCONCELLOS, A., MÉLO, ACS., VASCONCELOSSEGUNDO, EM. and BANDEIRA, AG., 2005. Cupins de duas florestas de restinga do nordeste brasileiro. Iheringia - Série Zoologia, vol. 95, no. 2, p. 127-131.

VITT, LJ., 1991. An introduction to the ecology of Cerrado lizards. Journal of Herpetology, vol. 25, no. 1, p. 79-90.

VITT, LJ. and VANGILDER, LD., 1983. Ecology of a snake community in Northeastern Brazil. Amphibia-Reptilia, vol. 4, no. 2-4, p. 273-296.

VRCIBRADIC, D., ROCHA, CFD., BURSEY, CD. and VICENTE, JJ., 2002. Helminth communities of two sympatric skinks (Mabuya agilis and Mabuya macrorhyncha) from two 'restinga' habitats in southeastern Brazil. Journal of Helminthology, vol. 76, no. 4, p. 355-361. 